IZA DP No. 8827

\title{
Gary Becker: Model Economic Scientist
}

James J. Heckman

February 2015 


\title{
Gary Becker: Model Economic Scientist
}

\author{
James J. Heckman \\ University of Chicago, \\ American Bar Foundation and IZA
}
Discussion Paper No. 8827
February 2015

\author{
IZA \\ P.O. Box 7240 \\ 53072 Bonn \\ Germany \\ Phone: +49-228-3894-0 \\ Fax: +49-228-3894-180 \\ E-mail: iza@iza.org
}

\begin{abstract}
Any opinions expressed here are those of the author(s) and not those of IZA. Research published in this series may include views on policy, but the institute itself takes no institutional policy positions. The IZA research network is committed to the IZA Guiding Principles of Research Integrity.

The Institute for the Study of Labor (IZA) in Bonn is a local and virtual international research center and a place of communication between science, politics and business. IZA is an independent nonprofit organization supported by Deutsche Post Foundation. The center is associated with the University of Bonn and offers a stimulating research environment through its international network, workshops and conferences, data service, project support, research visits and doctoral program. IZA engages in (i) original and internationally competitive research in all fields of labor economics, (ii) development of policy concepts, and (iii) dissemination of research results and concepts to the interested public.
\end{abstract}

IZA Discussion Papers often represent preliminary work and are circulated to encourage discussion. Citation of such a paper should account for its provisional character. A revised version may be available directly from the author. 
IZA Discussion Paper No. 8827

February 2015

\section{ABSTRACT}

\section{Gary Becker: Model Economic Scientist}

This paper presents Gary Becker's approach to conducting creative, empirically fruitful economic research. It describes the traits and methodology that made him such a productive and influential scholar.

JEL Classification: B31, D13, J13, J24

Keywords: empirical economics, human capital, discrimination

Corresponding author:

James J. Heckman

Department of Economics

University of Chicago

1126 East 59th Street

Chicago, IL 60637

USA

E-mail: jjh@uchicago.edu

\footnotetext{
* This research was supported in part by the American Bar Foundation and NIH grants NICHD R37HD065072, NICHD R01HD54702, and NIA R24AG048081. The views expressed in this paper are solely those of the authors and do not necessarily represent those of the funders or the official views of the National Institutes of Health. I thank Burton Singer for helpful comments.
} 
Gary Becker transformed economics by broadening the range of problems considered by economists and by creating new analytical frameworks. He founded flourishing fields of economics and public policy. It is said that Helen of Troy was "The Face that Launched a Thousand Ships." It can be said of Gary Becker that his ideas launched the production of hundreds of data sets and thousands of empirical and theoretical studies.

This paper discusses Becker as a model economic scientist whose creativity, curiosity, tenacity, openness to ideas and research methodology combined to produce a body of research that expanded the boundaries of economics and addressed fundamental questions of public policy 11 Becker wrote little on his methodology. He practiced rather than preached. A close examination of his approach across his many contributions reveals a consistent pattern that has important lessons for all economists seeking to conduct empirically fruitful economic research.

Becker's approach to economics was forged in the intense intellectual environment at the University of Chicago in the early 1950s when he was a graduate student. Milton Friedman had an important influence on Becker's methodology. Friedman consistently applied price theory and Marshallian partial equilibrium analysis to analyze a range of economic questions. Friedman (1949) contrasted the empirical fruitfulness of the Marshallian approach with the empirical sterility of Walrasian general equilibrium theory. Friedman also had strong views on how to do empirical work in economics. When Becker was a student, Friedman published his influential and controversial "Methodology of Positive Economics" (1953).

Becker was also influenced by others in that Chicago environment. As a student, he was a research assistant at the Cowles Commission at the University of Chicago, which had just developed and codified the framework of modern econometrics. The Cowles methodology featured sharp distinctions among the tasks of formulating economic models, identifying them and estimating them. It fostered the application of Neyman-Pearson theory to testing econometric models that had been formulated in advance of looking at the data.

Just before Becker arrived, Chicago economics had weathered the storm created by then Chicago professor Tjalling Koopmans' (1947) essay "Measurement Without Theory," which attacked the purely inductive approach to understanding business cycles adopted by Arthur Burns and Wesley Clair Mitchell (1946), a book that Milton Friedman had described as a paragon of economic science. Koopmans and the entire Cowles group advocated formal econometric approaches to understanding underlying economic mechanisms as guides to designing and interpreting economic data and to devising effective economic policies.

Becker absorbed all of these influences. Ever an independent thinker, he developed a unique synthesis of these approaches to address a range of new economic problems. He was flexible and used any approach that was useful in

\footnotetext{
${ }^{1}$ In two previous lectures (Heckman $2014 b$ and Heckman 2014a), I have spoken on his life and work. This paper extracts material from Heckman (2014a) and extends it. A video of that lecture can be found at http://youtu.be/Xw3fd0xIP6M
} 
solving a problem. For example, he departed from the Marshallian script when he used dynamic general equilibrium theory in his generalizations of Malthusian population theory (Becker, 1991). He rejected the purely inductive approach of Burns and Mitchell that "facts could speak for themselves." Like Koopmans, he strongly believed that all measurements needed to be guided by theory. Like Friedman (1953), he also rejected a purely theory-based approach to economics and the sharp distinctions among the tasks of theory creation, model identification, estimation and inference that were featured in the Cowles approach to econometrics ${ }^{2}$ He often said "economics is a dialogue between theory and data and should never be either one or the other." Becker appreciated that any distinction between model and data is always imprecise. Data suggest theories. The theories so constructed are best tested with new data (fresh samples of data) and by considering and testing additional implications of the theories.

This paper describes Becker's methodology which, coupled with his intense intellectual curiosity and willingness to engage ideas, however hostile their bearer, produced a powerful body of economic analysis. He was highly creative in pursuit of answers to big questions in economics and had many "eureka" moments in his career. I first describe his methodology and then give several examples of its application.

\section{Becker's Methodology}

Becker created a powerful body of economic science. He did so by relentlessly applying three principles: (a) economic agents act in their self interest (broadly defined and ever more broadly defined over his career); (b) preferences are stable (but they can evolve through practice, habituation, learning and hence they can differ among people); and (c) markets - broadly defined - are in equilibrium (both formal markets and informal nonmarket settings using explicit and implicit "shadow" prices respectively) (Becker, 1978). Studying carefully the facts of any phenomenon he was attempting to explain, and using economic theory guided by these three principles, he proposed plausible hypotheses. He used simple models that are faithful to the data, that are consistent with economic theory, that have predictions over a broad range of phenomena beyond those being investigated, and that are fruitful in suggesting new hypotheses. He admitted failures, constructively engaged his critics, and creatively responded with fresh insights and new models.

The constant interplay between theory, data, and revision of the theory are core features of science. This interplay was an essential component of Friedman's "Methodology of Positive Economics." Becker's parsimonious yet content-laden models evolved to fit the facts. This approach to model building is the essential feature of the scientific method. It is neither purely inductive or deductive. It is abductive. Abduction - the back and forth between hypotheses (as encoded in models) and data - is the essence of serious science. It can be said that Becker "abducted" economics. He sought the most plausible and coherent set

\footnotetext{
${ }^{2}$ See Friedman $\sqrt{1953}$, footnote 11) for his opinion about the Cowles methodology.
} 
of explanations consistent with the available data 3 In many of his efforts to understand economic phenomena, he brought creative insights in response to initial mismatches between models and data.

Becker developed his own approach to economic analysis, drawing on the diverse currents of thought swirling at Chicago in his student days, taking what he perceived as the most scientifically fruitful elements of each. He practiced and advocated measurement with theory. He freely used general equilibrium models when they were empirically fruitful. He actively abducted, going back and forth between his models and the data, learning from that interaction, producing creative insights to empirical challenges and thereby illuminating the understanding of big problems.

\section{Example: Fertility, Household Production, and the Economics of the Family}

Becker's research on the economics of fertility exemplifies his evolution in thinking as guided by data, his willingness to acknowledge initial empirical failures and to creatively respond to them. It also illustrates his ability to focus on problems over long stretches of time. This research eventually branched out to the corpus of his work on household production, marriage, and the economics of the family (Becker, 1991).

Before Becker, the dominant view of fertility among economists was Malthusian: as incomes rose, fertility rose until over-population ensued and drove down incomes, producing starvation and death. Eventually incomes would rise as people became more scarce. This model was grossly inconsistent with the facts for developed countries, even by the late 19th century. Yet it was not until his pioneering analysis (1960) that economists began to systematically develop an alternative model consistent with the evidence.

His first paper on the topic treated babies as consumer durables and maintained a Malthusian focus on income effects. Children were normal goods. The negative correlation between family income and fertility found in cross-sectional data was attributed to the greater contraceptive knowledge of higher income families. The paper was harshly — and sometimes hysterically — criticized by many who rejected the notion that babies were like consumer durables and were costly

More useful criticism came from his discussant James Duesenberry (1960) who faulted Becker for not recognizing how the consumption of any child is closely tied to the consumption of other children in the family and to the parents' level of consumption. Children are no ordinary good. Within a household, what is done for one is usually done for all. With rising income, the demand for higher standards of living and higher levels of child quality increases. In this

\footnotetext{
${ }^{3}$ See Igor Douven (2011) for one definition of abduction. Heckman and Singer (2015) discuss abduction as a tool for economic analysis.

${ }^{4}$ Becker (1978, 1991) summarizes the hostile initial reception to his work.
} 
way, the cost per child increases. Becker absorbed this criticism and, after a long gestation period, responded creatively to it.

On the way to crafting his response, a significant advance in his thinking was suggested by his Columbia colleague and collaborator, Jacob Mincer. Together Becker and Mincer organized the Columbia Workshop in Labor Economics that fostered research that revolutionized the field. Mincer (1963) noted the importance of the price of women's time as a relevant opportunity cost for analyzing fertility and female labor supply. Becker formalized and expanded these ideas in his household production model - a theory that treated children as household outputs valued in final utility with a leading input being mother's time $5^{5}$ He organized thinking about home production and stimulated research that collected new data on household time use, home production, and a variety of nonmarket activities including health, fertility and crime. He developed equilibrium concepts for these nonmarket activities using shadow prices to clear the implicit markets.

He built on this work by incorporating a delayed but thoughtful response to Duesenberry. He linked expenditures on a child's quality to the expenditures on other children in the family (Becker, 1991). Growth in income leads to a growth in the demand for child quality which raised the implicit price of children. This leads to a trade-off between quality and quantity that, under plausible conditions satisfied in all modern economies, leads to fewer but higher quality children being produced as incomes, and especially the price of female time, increased. As women become more educated, the opportunity cost of children increases. Policies that promote education reduce fertility.

This research explains a major phenomenon: the decline in fertility with economic development. It also explains why, even if China relaxes its One Child Policy, there will be important forces at work containing any increase in fertility.

Becker did not stop there. Once he started an investigation, he stayed with it. He probed more deeply into the functioning of households and their formation. He modeled the marriage market as a sorting and matching mechanism, and considered its implications for marriage and divorce and for child development (Becker, 1991). He embedded his previous work on fertility into a dynastic general equilibrium model and created new models of fertility and growth that replaced the Malthusian model with an empirically concordant framework. The abductive give and take between model and data characterized this research and made his contributions both intellectually innovative and empirically fruitful.

\section{Example: Human Capital Theory}

As a second example, consider Becker's work on human capital. As discussed in Becker (1993), generations of earlier economists (starting with Adam Smith, 1776) had discussed the notion that human skills can be created. Yet in the early 1960s, skills were largely ignored by mainstream economists working on

\footnotetext{
${ }^{5}$ See Heckman (2015) for a summary of this approach.
} 
economic growth, national income accounting, and labor economics. Friedman and Simon Kuznets (1945) had developed elements of the modern theory of human capital, computed rates of return to specific types of occupational training, and introduced the distinction between general and specific human capital. Yet their theory was mostly implicit and their emphasis was largely empirical.

Becker tied diverse strands of the literature on human capital together in a unified and parsimonious theoretical framework that went to the heart of the central issues in skill development. His theory addressed a diverse array of empirical regularities. Among other phenomena, he explained (a) the determinants and economic consequences of schooling; (b) on-the-job training and life cycle wage growth; (c) the quit and layoff decisions of workers and firms; and (d) patterns of trade among countries (Becker, 1993). It is a brilliant example of abductive economic science at its best. The power of the theory came from its ability to explain a wide array of phenomena that had previously been viewed in isolation from each other.

\section{Example: Accounting for Tastes}

The treatment of preferences by economists fascinated Becker. He took various positions on preferences over his lifetime (see Becker, 1996). Like any scientist, he rejected tautological explanations of phenomena based solely on differences in preferences or on changes in tastes. Such explanations are too facile and often phenomenon-specific with little generality. Here, as elsewhere, he sought theories that predicted a broad array of phenomena based on constraints and technology.

Early in his career, Becker (1962) showed that many of the basic predictions of consumer theory came from variations in constraints, not from the properties of consumer preferences. Irrational but constrained agents still obey the law of demand. Preferences added to this story but are not the fundamental driving force.

His work on household production (Becker, 1965) relieved part of the burden placed on preferences in explaining consumer demand and labor supply by isolating the role of production of final goods and the role of technology and constraints in shaping economic choices. This research stimulated a large body of research on time use and household production.

In an influential article with George Stigler (1977), he rejected tautological taste-based explanations and began a research agenda on the origins of preferences on which he worked until the end of his life. This paper responded to a body of research that noted that preferences appeared to change over time, and claimed that individuals have multiple selves and hence act inconsistently (see e.g., Thomas Schelling, 2006). Becker and Kevin Murphy (1988) showed that preferences can change through choices made by agents. But the agents act rationally, and under certain conditions, their choices are time-consistent. Preferences are stable but the arguments of preferences change through consumption decisions and choices of lifestyle. They built a model of rational habit 
formation that includes addiction. The model has been applied to the analysis of smoking (Becker, Michael Grossman and Murphy, 1994) and to the evolution of health (Heckman and Rong Hai, 2014). Becker also addressed the formation of the preferences of children by parents for selfish, altruistic, or paternalistic purposes to help complete missing markets (Becker, 1996).

\section{$5 \quad$ Becker as an Empirical Economist}

While Becker is not known primarily for conducting original empirical research, his knowledge, syntheses, and insights of the empirical evidence on every question he addressed were comprehensive. He closely followed, encouraged, and thoughtfully commented on a huge array of empirical economic research. His pioneering microeconomic analyses were developed at a time when large-scale micro data were beginning to be collected on earnings, fertility, and labor supply. These data challenged and sharpened his theories and his theories guided the collection of new data. Becker created frameworks that shaped and guided collection of data on time use, returns to education and ability bias, determinants of educational choices, crime, household formation and dissolution, fertility, addiction, life cycle labor supply, and on the study of intergenerational mobility, to name only a few of his many contributions.

\section{Becker's Approach to Policy Analysis}

Becker approached the study of public policy by attempting to understand the underlying mechanisms generating the problems studied and by using this knowledge to suggest effective policies. In the language of contemporary applied econometrics, he went beyond the study of treatment effects to understand the mechanisms producing the treatment effects. A splendid example is his research going behind the statistical estimates of intergenerational mobility (Becker, 1991).

\section{Summary}

Gary Becker made brilliant and insightful contributions to economic science by addressing a wide range of economic and social questions. In doing so he broadened the scope and method of economics. He achieved this feat by applying his own distinctive version of the abductive scientific method. His research was guided by a core set of basic principles that he relentlessly applied and expanded as required to solve new problems. As he evolved, the entire profession evolved with him, expanding its tools and horizons. His willingness to acknowledge the limitations of his work, to constructively engage all of his critics, and to creatively respond to criticism and initial empirical failures led to a productive life of innovative scholarship. 


\section{References}

Becker, Gary S. 1960. "An Economic Analysis of Fertility." In Demographic and Economic Change in Developed Countries., ed. George B. Roberts, Chairman, Universities-National Bureau Committee for Economic Research, 209-240. Columbia University Press. National Bureau of Economic Research, http://www.nber.org/chapters/c2387.

Becker, Gary S. 1962. "Irrational Behavior and Economic Theory." Journal of Political Economy, 70: 1-13.

Becker, Gary S. 1965. "A Theory of the Allocation of Time." The Economic Journal, 75(299): 493-517.

Becker, Gary S. 1978. The Economic Approach to Human Behavior. University of Chicago Press Economics Books, Chicago:University of Chicago Press.

Becker, Gary S. 1991. A Treatise on the Family. . Enlarged ed., Cambridge, MA:Harvard University Press.

Becker, Gary S. 1993. Human Capital: A Theoretical and Empirical Analysis, with Special Reference to Education. . 3rd ed., Chicago:University of Chicago Press.

Becker, Gary S. 1996. Accounting for Tastes. Cambridge, Mass.:Harvard University Press.

Becker, Gary S., and Kevin M. Murphy. 1988. "A Theory of Rational Addiction." Journal of Political Economy, 96(4): 675.

Becker, Gary S., Michael Grossman, and Kevin M. Murphy. 1994. "An Empirical Analysis of Cigarette Addiction." American Economic Review, 84(3): 396-418.

Burns, Arthur F., and Wesley Clair Mitchell. 1946. Measuring Business Cycles. Studies in Business Cycles, New York:National Bureau of Economic Research.

Douven, Igor. 2011. "Abduction." In The Stanford Encyclopedia of Philosophy. , ed. Edward N. Zalta. Stanford:Stanford University Press.

Duesenberry, James S. 1960. "Comment on "An Economic Analysis of Fertility" by Gary S. Becker." In Demographic and Economic Change in Developed Countries. 225-256. New York, NY:National Bureau of Economic Research.

Friedman, Milton. 1949. "The Marshallian Demand Curve." Jounal of Political Economy, 57(6): 463-495.

Friedman, Milton. 1953. "The Methodology of Positive Economics." In Essays in Positive Economics., ed. Milton Friedman. Chicago, IL:University of Chicago Press. 
Friedman, Milton, and Simon Smith Kuznets. 1945. Income from Independent Professional Practice. New York:National Bureau of Economic Research.

Heckman, James J. 2014a. "The Impact of Gary Becker's Work, (Lecture)." The University of Chicago, A Celebration of the Life and Work of Gary S. Becker, http://youtu.be/Xw3fdOxIP6M.

Heckman, James J. 2014b. "Private Notes on Gary Becker." IZA Discussion Paper. No. 8200.

Heckman, James J. 2015. "Introduction to 'A Theory of the Allocation of Time' by Gary Becker." Forthcoming, The Economic Journal.

Heckman, James J., and Burton Singer. 2015. "Abducting Economics." Unpublished manuscript, University of Chicago, Department of Economics.

Heckman, James J., and Rong Hai. 2014. "Estimating the Dynamic Causal Relationship of Health, Education and Wealth." University of Chicago, Department of Economics.

Koopmans, Tjalling C. 1947. "Measurement Without Theory." The Review of Economics and Statistics, 29(3): 161-172.

Mincer, Jacob. 1963. "Market prices, opportunity costs, and income effects." In Measurement in Economics., ed. C. Christ, 67-82. Stanford:Stanford University Press.

Schelling, Thomas C. 2006. Micromotives and Macrobehavior. New York, NY:W. W. Norton \& Company.

Smith, Adam. 1776. An Inquiry into the Nature and Causes of the Wealth of Nations: Volume I. New York:Cosimo Classics. Edition published November, 2007.

Stigler, George J., and Gary S. Becker. 1977. "De Gustibus Non Est Disputandum." The American Economic Review, 67(2): 76-90. 